\title{
SIMPLE COMPANY ON SHARES AS STARTUP SUPPORT TOOL
}

\author{
Tomáš Peráček , Boris Mucha², Patricia Brestovanská2, Jana Kajanováa \\ ${ }^{1}$ Department of Information Systems, Faculty of Management, Comenius University in Bratislava, Šafárikovo \\ námestie 6, 81499 Bratislava, Slovak Republic \\ ${ }^{2}$ Department of Economics and Finance, Faculty of Management, Comenius University in Bratislava, Šafárikovo \\ námestie 6, 81499 Bratislava, Slovak Republic
}

To cite this article: PERÁČEK TOMÁŠ, MUCHA BORIS, BRESTOVANSKÁ PATRICIA, KAJANOVÁ JANA. 2018. Simple Company on Shares as Startup Support Tool. Acta Universitatis Agriculturae et Silviculturae Mendelianae Brunensis, 66(6): 1601-1611.

To link to this article: https://doi.org/10.11118/actaun201866061601

\begin{abstract}
On January $1^{\text {st }}$ 2017, the amendment to the Commercial Code implementing the Capital Market Concept. This is a measure of the implementation which is the part of the Startup Support Concept and the Development of the Startup Ecosystem in the Slovak Republic. A new form of capital trading company has been created to offer a comprehensive solution for capital investments in companies. An example of such an investment is start-up investment as business initiatives with high innovation and growth potential that can not provide funding through banks. When investing capital, it is necessary to flexibly set the investor's entry, coexistence and output beyond what is currently possible in the form of trading companies in the conditions of the Slovak Republic. Until now, it has been a limited liability company, which has been mainly used for investing capital of start-ups. Later was used the joint stock company as the capital-intensive type of business. A public limited company and a limited partnership belonging to a group of private partnerships were not and are not used as startups, because of unlimited liability of the partners for the company's obligations. The main obstacle for a joint-stock company, as support for startups until their advanced stages of life cycle, is relatively high statutory minimum capital requirement of EUR 25,000. Another issue may be legal regulation aimed at medium and large businesses allowing them to trade their shares on the stock Exchange market, with the associated increased demands to ensure the functioning of the company. However, the Simple company, representing the hybrid form of a capital company, also has its serious shortcomings and is not a boon to support startups. Since it is a "young" type of business company that has not yet been the subject of research, it is the intention of the contributors to analyse a Simple company on shares and, by means of a number of scientific research methods, to provide a critical view of its shortcomings. Despite the fact that the reason for the establishment of this business company was mostly economic, research is mainly directed at the area of commercial law.
\end{abstract}

Keywords: investment, simple company on shares, startup, support

\section{INTRODUCTION}

Startup is world-wide rapidly expanding type of business. It takes advantage of an Internet connection that allows it to expand very easily to many countries. It is a type of innovative business that allows founders try to create a new product or service. Its goal is to satisfy a certain need through a non-existing service or product. However, it is not excluded that the startup could develop an existing product or service, but with the help of a significant innovation, whose main advantage is competitiveness in the global market environment. 
The intention of the authors of this article is to explore the unconquered field, which is a simple company on shares and to provide a comprehensive view. On the basis of the research, we want to confirm or reject the hypothesis that a simple company on shares is a suitable tool to support start-up entrepreneurs.

From the study of available literature, it can be concluded that the literature and magazines prevail and study long-standing types of business. Several theoreticians in the field of business law have been or are engaged in Slovakia, including J. Suchoža, M. Pataky, M. Mamojka and P. Kubíček and others. Their professional opinions and scientific arguments are mainly found in the textbooks of business law and commentaries on the Commercial Code. Business authors have also paid attention to authors in the Czech Republic, among which we can mention renowned experts such as J. Dědič, J. Pauly, P. Csach, and others. A special area as a source of literature belongs to the decision-making activities of the Slovak courts as well as statistical data obtained from the Commercial Register of the SR and the Statistical Office of the Slovak Republic.

Due to the nature and complexity of the studied subject, we apply several scientific methods of knowledge. This is a highly qualified human activity aimed at acquiring scientific knowledge as well as penetrating the phenomenon to its core. As a result of this activity, new knowledge will be organized into a system. In our research we consider it particularly appropriate to use the logic method, which sets certain rules of human judgment, which have been formed by many years of experience and their observance guarantees the order of thoughts, its correctness and under certain assumptions, its truthfulness. We also applied the analytical method to analyze the legal status and legal regulation from the scientific methods of knowledge. Another method used, synthesis allows us to monitor the relationships between the facts, the nature of the interrelationships between them, to discover the causes. Due to the nature of our contribution, it is also necessary to use the comparison method. This is of great importance in explaining the processes of change, evolution, the dynamics of the studied relationship, the discovery of tendencies, and the patterns of its development. We find its application when comparing a simple company on shares with a joint stock company, a limited liability company as well as a Czech legal order. We will also use it to make different views on the legislation and interpretation of individual institutes. Finally, it will find its use when comparing statistic data. Based on scientific knowledge of valid and effective law and legal science, we used some deduction methods based on general assumptions and related to individual general or partial conclusions in some parts of the work. Although doctrinal interpretation is not legally binding, it is based on the scientific knowledge of valid law by recognized personalities and therefore we consider its application as key.

\section{Generally about startup}

Normal The legal definition of this term is not part of the Slovak legal order. Nevertheless, it is necessary to base ourselves on the content of the explanatory memorandum to bill no. 389/2015 Coll. amending Act no. 513/1991 Coll. of Business Code. This amendment introduced a third type of Capital Company into our legal system. It is a simple company on shares characterized as an entrepreneurial initiative with high innovation and growth potential that cannot secure financing through banks. In the case of risk capital investments in companies, a flexible adjustment of the investor's entry, coexistence and exit is necessary beyond current business forms in the Slovak legal order (Reason Report, 2015).

However, the effort to create a definition of this concept can still be found in the Concept for Startup Support and the Development of the Startup Ecosystem of the Slovak Republic, published by the Ministry of Finance of the Slovak Republic, which contains two definitions. The first one focuses on the growth and innovation potential of startups and, in its view, "start-ups of entrepreneurship initiatives with high growth and innovation potential that can launch and support smart and inclusive economic growth in the long run and also attract foreign investment. The second definition of innovation and startup scalability are characterized as emerging business companies that try to apply innovative approaches to problem and have high potential for scalability (Ministry of Finance of Slovak Republic, 2015).

The basic problem for the startup is the right choice of legal form of business. In general, this decision has a crucial impact on the viability of the startup, because each legal form of business has different requirements for its establishment as well as for further functioning. The crucial and perhaps decisive issue is the question of the need and the amount of the capital, the need to register in a business or other register, or the need to conduct double-entry bookkeeping. Especially, in the case of the choice of business in the form of a business company, the key issue is company bodies, which has a major impact on the efficiency of management (Wojčák, 2017). In general, the more complicated the legal form, the more authorities are needed and the legal relationships between them are more complex. The legal order of the Slovak Republic recognizes several forms of business. The simplest is doing business through a trade license. A special place includes business in other forms governed by European Union rules. However, the most used form is doing business in the form of capital companies, and there are some pitfalls, and this was, according to the legislator, the main reason for the emergence of a simple company on shares that is the subject of our investigation. 


\section{A simple company on stock}

Slovak commercial law was the subject of a major change in 2001 before the adoption of the amendment to the Commercial Code in 2015. It was a process of harmonizing our law to get possibility to enter the European Union. With the exception of the European Company and the European Cooperative Society, no new type of business has been introduced since 1991. For this reason, we can look at a simple company for shares as the first legal form created by the Slovak legislator without transferring a European template.

The adoption of a simple company for shares as a legal form of a capital company with a considerably higher degree of flexibility in the regulation of internal relations can therefore be seen as a positive step by the legislator. In essence, it is the legislator's response to the business practice of finding a legal form that facilitates easier financing.

From the point of view of the system of the Commercial Code, the legislation of a simple company on shares is contained in Paragraphs $220 \mathrm{~h}$ to $220 \mathrm{zl}$ and it starts with a legal definition that is identical to the definition of a joint stock company. According to it, a company with registered capital is allocated to a certain number of shares of a certain nominal value. This is the third type of capital company regulated in the Commercial Code. Even a simple company as a businessperson is responsible for violating their obligations with all his assets, regardless of the amount of the basic capital. The shareholder is not liable for the liabilities of the joint-stock company and the company is not responsible for the obligations of its shareholder. In the event of any damage arising from the failure of shareholder's obligation to repay the share resulting from the foundation agreement, it does not correspond to the joint stock company as it is the obligation of the shareholder and not of the company (The Supreme Court of Slovak Republic, 2001). The decision on how to create a business name is the founder's responsibility; it must also include an addendum containing the legal form "simple company on shares or statutory abbreviation "s.c.s.". In particular, the form of business is part of a business name and it is necessary to add it. However, in the case of litigation, this deficiency cannot be regarded as an unavoidable obstacle but as an incomplete submission that the court may remove (The Supreme Court of Slovak Republic, 1997).

The basic condition for the existence of a simple company on shares is the issuance of at least one share as a security, which can be defined in two ways; economic as well as legal. From an economic perspective, it represents a special asset that, through its function on the financial market, allows the conversion of money into capital. Financial assets are important tools for realizing financial investments in the economy (Miháliková and Horniaková, 2002). According to legal theorists (Dědič and Pauly, 1994), it is a document (written expression of will) in which a right is founded (incorporated), the fundamental of the security is that the administration of this right and its treatment is only possible with this document. The Securities Act in Statute 2, Paragraph 1 defines a security as a valuables a valuable record in the statutory form and form connected with this Act and the rights under special laws, in particular the right to claim certain property or to have certain rights against designated persons. If this entry is made on a paper, it is a paper security, but if it is made in a securities register, it is a book-entry security.

Eliáš (2000) is of the opinion that, after the issue of the share as a security, the rights of the shareholder as shareholder of the company are associated with the share. The mandatory Statute of Paragraph 220 restricts the company to decide to issue shares because, from the point of view of the form, it is possible to issue shares only in book entry form and it can only be shares on name. The fundamental difference in comparison with the joint stock company was also observed in the impossibility of issuing priority shares. Another difference is that a simple company on shares can only issue ordinary shares and shares with special rights, including the right to information, the right to profit, or the liquidation balance. Unlike a joint stock company, a founding charter, a founding or company statutes may determine that the nominal value of the shares is expressed in euro cent or in a combination of euro and euro cent. It follows that the minimum value of one share may be set at one eurocent. Shares with special rights include a designation of their kind, their number and a reference to the provision of the statutes in which special rights are regulated. The shares with the same special rights are one type of shares. A number of special rights may be connected to shares with the same nominal value, which in practice means that part of the right may be connected with the right of information or the special right can be the profit share.

Schmidt (1999) argues that, the fundamental right of a shareholder is the right to participate in the management of the company. However, this right may also be limited because the Commercial Code permits the issue of a share with which no voting rights are connected, but only if the voting rights are at least one share of the company. However, the Statutes of Paragraph 220i, Section 7, also entitles the holder of such shares to the right to vote at a general meeting when voting by type of shares.

The distinctive feature of a simple company on shares is the duty of the court to abolish the company and perform its liquidation - monetization of the property, if it finds that the company does not have at least one shareholder owning the share with which the voting rights are connected or the voting rights cannot be performed in the company. This means that the legislator has removed the possibility of deciding of the court whether the company is abolished or not by the Statutes of Paragraph 68 of the Commercial Code. 
Unlike a stock company that maintains a list of its shareholders, a simple company on shares secures this obligation through the Central Securities Depository in Bratislava or the National Securities Depository.

It is clear from the analysis of the case law (The Supreme Court of Slovak Republic, 2003) that the company's general meeting also includes a change in the Articles of Association in that part concerning the form of the company's shares. However, the statutes may limit or exclude the transferability of shares or only certain types of company shares. Furthermore, the wording of the Articles of Association concerning the limitation or exclusion of the transferability of the shares and the conditions for the redemption of such shares by a company may be changed only with the consent of the qualified two-thirds majority of the shareholders who own the shares. However, if a situation arises that the shares would be transferred to another person in breach of the limitation or exclusion; such a legal act would be affected by an absolute nullity and would not have the rights or obligations from such transaction.

Another novelty is the introduction of the exclusion of the transferability of the shares, which has not yet been possible. Paragraph 156, Section 9 of the Commercial Code allowed only temporarily limiting the transferability of registered shares. In simple company on shares, the transferability of shares or some type of shares may be excluded for a maximum period of four years from the repayment of their emission rate. However, its expiration gives the shareholder the right to demand the redemption of those shares by the company and this right is not subject to limitation.

According to Kubinec (2015) in particular, investors should have an option after 4 years after payment of the emission rate, to require the company to buy back shares. The shareholder's request to the company to buy back its shares is, from the point of view of the theory of law, a unilateral legal act by which the company proposes to conclude a contract for the purchase of a security. The company's freedom of contract is limited, however, as its law imposes an obligation to buy these shares for the appropriate emission. It is necessary for the contract to include a proper arrangement of the conditions, the fairness of the purchase price, its maturity so that the purchase of the share by the company does not have a negative effect on its creditors.

If buying a share had a negative effect on the creditors, we agree with the legislator's view that it is the company's duty to refuse to execute the transaction as it is meant by Statute 220 of the Commercial Code. If the shareholder's right does not allow to buy the share to be realized by a company and if it had negative consequences, for example, its equity would be less than the value of the share capital together with the reserve fund, or if the company is in crisis, bankruptcy or as a result of the redemption of shares, it would be in crisis or bankruptcy, or the company had not at least one shareholder as a result of the redemption of shares. However, neither the statutes nor the law allow them to return their investment. Another problem can be the financial situation of the company and the lack of funds for the purchase of own shares. But even with such a problem the investor has to count, especially because some experts (Žitňanská, 2000) characterize the shares as a speculative security. They justify their position by claiming that investment in shares is a risky investment and that the legal order cannot eliminate the economic risk arising from the substance of the investment into the shares.

\section{Establishment and formation of the company}

The establishment and formation of a company basically do not differ from the establishment and formation of other types of companies with certain differences. In this case, it is necessary to distinguish between the two phases. The first is the establishment of a company that is established on the conclusion of a founding covenant or the writing of establishing charter. As with the joint-stock company, the legislator insists on a specific form, which is the notarial record of a legal act (Mamojka, Bohrová, Ušiaková et al., 2016). Unlike a joint stock company, however, it may also be established by one natural person or legal entity, and the number of founders is not, as opposed to a limited liability company, limited. As we have already mentioned, a simple company on shares belongs to a capital company and therefore has to create a certain basic capital in a minimum of one euro. However, such a low capital must be allocated into a certain number of shares, with the nominal value of the share and their name. Unlike a joint stock company, it cannot be based on a call for share subscription. In particular, we also need to point out the necessity of repaying the full value of the share capital before the company's establishment. The founding and founding charter have the same obligatory content requirements as prescribed by law. These are the most basic data that characterizes a simple company on shares and which needs to be clarified as a basis for establishing a company. According to Krejci (1995) in the first place, the business name must be also included with a legal form. The law does not lay down specific requirements for determining the seat of a company. However, with regard to the subject of business, it must be clearly defined and it is not permissible for a company to be established for a purpose other than business. In determining the amount of the basic capital, the founders may use a wide range of laws to respect the minimum amount of the basic capital, with the sum of the nominal values of the share being equal to the amount of the capital. The nonmonetary deposits of the founders are compulsorily valued by an expert's report made by a court expert. 
Since the founding treaty and founding document also include the Company's Articles of Association, we emphasize that this document also contains a declaration by the founders that they approve the statutes of the company, which must have the same requirements as the Articles of Association of the joint-stock company. In general, they also contain an indication of the issued types of shares, with which the same special rights are connected, as this is meant by the provision of Paragraph 220i, Section 4 of the Commercial Code, in particular when determining the share of the profit or the liquidation balance. The mandatory part of the Articles of Association is also the determination of dealing which the rights to each type of shares as well as the determination of the limitation of the voting right to the same extent on all shares of the same kind. Founders must also agree on members of the company's bodies. It is a board of directors and a supervisory board, but it is only a faculty body. It is possible for them to set a monthly remuneration in their statutes, and such an act, in the opinion of the court (The Supreme Court of Slovak Republic, 2002), is not contrary to the provisions of the Commercial Code. It emphasizes the need to distinguish the remuneration of the function from the determination of their shares in the profit (royalties), as this right belongs to the general meeting and only in the case of the profit obtained.

\section{Company authorities}

An analysis of the Paragraph 220za of the Commercial Code shows that a simple company for shares has appointed the legislator the same structure of bodies as a joint stock company, with the highest authority named general meeting. However, it did not consider it is necessary to devote a specific area of rights and obligations, which is why the subsidiary provisions of the Commercial Code on a joint-stock company should be applied in addressing these issues.

The supreme body of the company is the general meeting consisting of shareholders authorized to decide on selected issues. It is, for example, to change the statutes, increase or decrease of the basic capital, issue bonds and shares, election and dismissal of members of the bodies of the company, including determination of the remuneration for the performance of the function or approval of the annual accounting documents.

According to Šuleková (2014) is the right of a shareholder to attend this meetings personally or on behalf of a shareholder by written mandate. It is essential that the General Meeting is held at least once a year within the time limit set by the Statutes. It shall be invoked by the Board of Directors in the manner and within the time limits specified by the Statutes. The invitation to the general meeting or the announcement of the General Meeting contains minimum information such as the business name and seat of the company, the place, date and time of the general meeting, the marking if it is general or extraordinary meeting, the agenda of the meeting, the decisive date for applying the right to participate in the general meeting.

Paragraph 220za, Section 1 of the Commercial Code introduced a rule that the agenda of the General Assembly may be supplemented only with the participation and with the consent of all shareholders of the company entitled to vote. A similar principle applies to the change of the general shareholders' program of the joint-stock company. The difference is that the law insists on the participation and consent of all shareholders of the company, including those who are not entitled to vote.

Similarity with the joint stock company is also reflected in the fact that the approval of a qualified two-thirds majority of the shareholders owning the shares is required for the General Meeting's decision to change the rights connected to a certain type of shares and to restrict the transferability of the shares. We note the obligation that the authenticity of the signature of the Chairman of the General Assembly must be officially certified. However, the law does not state on what document it is necessary to certify the authenticity of the signature, which indicates a certain inconsistency of the legislator. Only by deduction we can assume that the minutes of the General Assembly will be held.

A further similarity with a joint stock company follows from the Paragraph 220za, Section 3, which deals with the approval of a change in the statutes, increases or decreases of the share capital, the appointment of a board of directors to increase the basic capital, issue of priority bonds or exchangeable bonds, abolition of a company or change of legal form (Janač, 2017). A minimum two-thirds majority of the shareholders was introduced. As the most basic issues of company's life, the need for the authenticity of the signature of the general assembly's chairman was introduced. But the fundamental difference is in its formal aspect. While a joint stock company is required to produce a record in the form of a notarial record of a legal act and thus also the presence of a notary in the general meeting, the simple company on shares is satisfied with the written record of the minutes and the signature of his chairman. The following paragraph 4 logically provides that, in the case of a single shareholder, a simple company on shares requires an official certificate of the authenticity of his signature on his decision made in the general meeting.

The law also includes the option for shareholders to decide on matters outside the general meeting, by correspondence. Such a method is possible under Paragraph 190a of the Commercial Code in a public joint stock company, but also in a limited liability company within the meaning of Paragraph 130 of the Commercial Code. However, the condition is that the statutes must allow it. In general, shareholders have 30 days to decide on 
the draft together with the necessary annexes, and the substantiations are sent to them by the Board of Directors. The required majority of the class is counted from the total number of votes of all shareholders. If the shareholder does not respond within the specified time limit, he/she does not agree with the proposal. However, as unharmed, we see the lack of determination of delivery method. It may be assumed that the legislature meant delivery through a post office (Dvořák, 2016). However, we are convinced that even delivery by e-mail is not excluded today.

The benefit of correspondent voting is the absence of the need for consideration of the resolutions of the General Meeting, as all shareholders are entitled to vote. The problem, however, is that professional literature sees the issue of non-delivery to a shareholder, whether due to an out-dated address, as impossibility or refusal to accept it. We believe that in such a case it is necessary to regard the decision as invalid, but only if the votes of the shareholder could influence the outcome of the decision. Csach (2009) states that if a proposal is not served on a shareholder, for example on the grounds that he does not stay at the address of delivery or if there is another barrier to delivery (failure to accept the consignment, refusal to accept it), in such a case it cannot be assumed that the shareholder disapproves the proposal, as it cannot, in principle, be agreed with the unknown. This view can be discussed.

A record must be made of the result of voting, but the law does not determine the person responsible (Dědič and Čech, 2006). In our opinion, the Board of Directors will prepare a record of voting. Based on the content of Paragraph 220zb, Section 4 of the Commercial Code, it is determined by him to announce the results of voting within 15 days from the expiration of the term of the shareholder's statement. Our point of view is also based on paragraph 6, according to which, if the Commercial Code requires an official certificate of authenticity of the signature of the Chairman of the General Assembly in the decisions of the General Meeting, the authenticity of the signatures of the members of the Board of Directors shall be officially certified. The general provision of the Commercial Code confers on each shareholder has the right to ask the Board of Directors to issue a copy or only a part, together with attachments, which the Board of Directors is obliged to execute without undue delay and send to the shareholder the address specified or give it to the shareholder in another way; otherwise it is obliged to provide it at the company's registered office. We emphasize that the shareholder is also entitled to issue a copy of the minutes of the General Meeting that took place before he became its shareholder. However, if the company has established a web site, it must publish the voting results, minutes and other documents within 15 days of the end of the general meeting.

\section{Board of Directors}

The statutory body of a simple company on shares is, as in the case of a joint-stock company, a board of directors. The company's management, acting on its behalf, decides on all matters of the company, unless it is subject to the General Assembly or the Supervisory Board by the Commercial Code or the Articles of Association. In general, each member of the Board of Directors is entitled to act on behalf of the company. Their names and the way they act on behalf of the company are entered in the business register. However, the statutes may remove some of the rights to act on behalf of the company, but this is part of the entry in the commercial register. However, the minimum number of members of the Board of Directors is, in our opinion, fundamental. As the law does not regulate this issue, the Board of Directors may not, in theory, be created as a collective body that will be the subject of discussion.

As an element taken from a limited liability company, we see the possibility for the statutes, unlike the joint stock company, to determine the unlimited duration of the term of office of the members of the board of directors. Paragraph 220c, Section 2, Letter b of the Commercial Code also introduced a strict requirement to approve all members' agreements with the General Assembly or the Supervisory Board or other bodies of the Company. However, the law does not directly address the consequences of the absence of consent. Patakyová et al. (2013) claims that the failure to grant such consent must be assessed in the same way as if the Supervisory Board did not approve an act in the sense of Paragraph 196a of the Commercial Code, where the doctrine concludes that such an act is invalidated, or its commitment to company is invalidated.

The primary role of the Board of Directors is to direct a company to achieve a profit or at least a balanced management. However, if the Board of Directors establishes that the Company has suffered a loss exceeding one third of its registered capital or is at least at risk of such loss, it shall inform the shareholders. Unlike the joint stock company, however, it does not have to convene a general meeting and put forward draft measures. Other duties of the Board of Directors, but only in the absence of the Supervisory Board, include the disclosure of information to shareholders beyond what is recognized by Paragraph 180, Section 1 of the Commercial Code. This provision allows them to seek clarification regarding the affairs of the company or matters of the persons controlled by the company that are related to the subject of the General Meeting. We believe that if the Board of Directors refuses to provide information, they can only go to the court with an action to determine the obligation to provide information, which in the SR is a dispute for at least 5 years with uncertain outcome. 
Members of the Board of Directors have a duty of information to the company itself, if their activities can conflict with interests between them and company. This is especially the case if they engage in business activities on their own behalf and on their own account or engage in business activities for others or participate in the business of another company as an unlimited liability partner. However, this provision is inconsistent as there is no sanction for non-fulfillment of the information obligation.

\section{Board of Supervisors}

In the question of the creation of the Supervisory Board, it finds similarity with a limited liability company, where the Supervisory Board is also credited only as a facultative body overseeing the activity of the statutory body (Ovečková et al., 2012). In particular, its role is to inspect all documents and records relating to the company's activities, to check that the accounting records are properly conducted in accordance with the facts, to review the financial statements that the company is required to prepare under a separate regulation and a proposal for profit distribution or to cover losses, their statements to the General Assembly and others. If shareholders decide to create a supervisory board, they must also include this fact in the Articles of Association. Subsequently, the provisions on a joint stock company, with one exception, apply to its position, scope, and manner of creation as well as its members' liability. It is not necessary for its members to be employees' representatives, irrespective of their number, but their participation in the supervisory board is not excluded; but will only depend on shareholders and employees. The members of the Supervisory Board also strictly apply the necessity of the approval of the General Meeting with a contract concluded between a member of the Supervisory Board and the company itself. We also take the view that, regardless of the company's Articles of Association, a rule on financial assistance and transfers of company assets to members of the Supervisory Board or their close relatives, or to persons acting on their behalf, as to the Paragraphs 196a of the Commercial Code.

\section{Change in the basic capital}

The increase in the capital of each trading company can be perceived, in particular, in relation to creditors as a positive step in showing a "healthy" business unit. For a simple company on shares, the law expires in a congenial way the possibility of increasing it by a public call for share subscription, in which the Board of Directors will appropriately publish the adjustment of the amount of the share capital. The special legal regulation in a simple company on shares permits the statutes to determine that the increase in the basic capital will not be decided at the general meeting, but that all shareholders are to be appointed by a qualified - two-thirds majority regardless of the type of action (Suchoža et al., 2016). The Articles of Association may limit or exclude the pre-emptive right to subscribe for the share capital increase, either for the owners of all the shares or for the owners of some of them. We point out the possibility to acquire shares for the stock also for other persons such as employees of the company. Entrepreneurs doing business under a trade license or non-trade license (e.g. lawyers) and the results of their activities for the company are subject to intellectual property rights.

The Statute of Paragraph 211 of the Commercial Code regulates the method of reducing the share capital of a joint stock company. It is a statute that is applied analogously to the needs of a simple company on shares. Its content suggests that the Board of Directors decides to reduce the basic capital by the Board of Directors by a two-thirds majority of the shareholders. Where multiple types of shares have been issued, this majority of the votes of the shareholders is required for each type of share. Statutes can exclude its application. In practice, this will mean that the proposal to reduce the registered capital will be decided by a two-thirds majority of all, not just the present shareholders

\section{Changing the legal form of the company}

The general regulation of the change of the legal form of the commercial company is found in Paragraph 69 of the Commercial Code, which implies the possibility of changing its legal form to another type of company or cooperative, unless the law stipulates otherwise. By changing the legal form, the company does not disappear as a legal entity. However, in the case of a simple company on shares, the second sentence of Paragraph 220 zl lays down two restrictions on the change of the legal form. In the first place, a simple company on shares can only be changed into a joint-stock company, and the second restriction is the impossibility of other companies and cooperatives to turn into a simple company on shares.

\section{Abolition of the company}

Also, the general provisions of Statutes 68 of the Commercial Code apply first and foremost to the abolition of a simple company. The company may be revoked voluntarily or by a decision of a state authority. In practice, this means that the company is being revoked:

- by expiry of the time on which it was based,

- from the date stated in the decision of the shareholders or the company body on the dissolution of the company,

- from the date specified in the decision of the company's winding-up court, other than the date on which this decision becomes final, Certain actions may be taken by the court of its own motion, (lat. "ex offo"). Section 68 (6) of the Commercial Code exposes the grounds on which the court may, at the request of a public authority, 
on the application of a person who certifies a legal interest or even on his own initiative, decide to abolish the company if:

a) the General Meeting has not been held in the relevant calendar year, or if the bodies of the company have not been appointed for more than three months,

b) the company loses its business license,

c) the preconditions laid down by the law for the establishment of the company,

d) the Company breaches the obligation to create or supplement a reserve fund according to the Commercial Code,

e) the Company breaches the obligation under Section 56 (4) of the Commercial Code- performs certain activities without the professionally competent people,

f) the company has not complied with the obligation to deposit individual financial statements in the collection of documents for at least two consecutive accounting periods,

g) the company does not meet the conditions under Statute 2 Paragraph 3 of the Commercial Code governing the legal person's registered office.

In this case the legislature provides the company with sufficient time to remedy these shortcomings, because if the court decides to abolish the company, it will set a time limit before the decision to abolish it, to remove the reason for the abolishing, if its abolishing is possible. Furthermore, it follows from the content of the law and in the event of a decision to abolish a company on the grounds of a registered office, the time-limit for abolishing of the reason for which it was proposed may not be less than 30 days.

The company's abolishing is preceded by liquidation even if its capital is transferred to a legal successor. Thus, liquidation is not required in selected cases such as the company's estate, or the rejection of a bankruptcy petition for lack of assets, and the abolishing of bankruptcy for lack of property (Kubíček et al., 2006).

It is clear from the case-law (The Supreme Court of Slovak Republic, 2009) that before the decision to abolish a company, the court is required by law to determine whether the company has business assets. If it finds that his business assets are sufficient to compensate for the reasonable expenses and remuneration for the performance of the liquidator's function, it shall decide to abolish the company and order its liquidation. Otherwise, it will decide to abolish it without liquidation. It should also be noted that the second sentence of Paragraph 68, Section 9 containing a legitimate presumption that when a company fails to comply with the obligation to keep accounts for two consecutive accounting periods, the court considers that the company does not have business assets that would be sufficient to compensate for reasonable expenses and rewards for the performance of the liquidator's function. This presumption can be refuted by the one who certifies the legal interest and demonstrates the opposite before the court's decision to cancel the company or opposite that the company has assets.

For these reasons, it is also possible to abolish a simple company on shares for other reasons, such as the social contract, the founding charter or the statutes of the company. In addition, these documents may give shareholders and members of the board a special right to seek redress from the company.

\section{Merging of companies}

The process of the merging simple company on shares is contained in Statutes 218a of the Commercial Code However, we refer to the special legal regulation of Paragraph 220i of the Commercial Code requiring that the merging contract also includes a specific adjustment of the rights of the shareholders participating in the process as well as their future rights to share in the profits of the successor company. An inseparable annex to this agreement is also a shareholder contract, but only in this case if such type of contract was concluded by the shareholders of the acquiring or successor company.

When merging companies, the basic rule is that only companies with the same legal form can join. In the case of a simple company on shares, however, another special Statue of Paragraph $220 \mathrm{k}$ breaks this limitation. It allows a simple company to be merged with a joint stock company, but a simple company disappears into shares and its capital goes to a joint stock company as a successor entity.

\section{Abolition}

The trade company shall abolish on the date of deletion from the business register, unless the Commercial Code provides otherwise. According to Augustinič (2006) at this time, the company disappears as an economic and legal entity, its ability to engage in economic activities as well as the possibility of entering into legal relations ceases. The deletion of the company from the commercial register is therefore constitutive.

\section{Research}

Our partial objective is also to examine the Czech legislation and to determine whether a similar type of business is part of its legal order. After the re-codification of private law in the Czech Republic, with the effect from January $1^{\text {st }} 2014$, the original Commercial Code was replaced by Act no. 90/2012 Coll. The Law on Commercial Companies and Cooperatives (Act on Commercial Corporations), (hereinafter "the Act"). In the opening section of Paragraph 1, it is stipulated that commercial corporations are commercial companies and cooperatives divided into three groups. The first group of companies is formed by a public company and a limited partnership as a personal business companies. Limited Liability Company and Joint Stock Company as well as the abolished Commercial Code encompass 
the law into a sub-group of capital companies. The European Company and the European Economic Interest Association are the third subtype of business companies. After examining the law and its individual legal institutes, we have found that a very similar type of business is a limited liability company. From its predecessor, contained in the Commercial Code, it differs from this type with number of features which the legislature has abandoned. It also shows certain features typical of personal business companies, the possibility of a partner to leave the company if the conditions laid down in Section 202, Paragraph 2, of the Act are met. As stated by Pokorná et al. (2015), as well as a simple company on the stock it is a very flexible type of business company, which can either be closed company with a dominant position or a company approaching the joint stock company. Elements of a limited liability company is almost identical to the simple company on shares, there is the need for very small deposits. Unlike a joint-stock company where Paragraph 246, Section 2 determines the minimum amount of the capital to 2 million Crowns (or EUR 80,000), the law of the limited liability company does not prescribe the minimum amount of the deposit. However, as it is apparent from Paragraph 142, Section 1, a limited liability company could also be characterized as a single-member commercial company, since a higher minimum deposit must be made only if the social contract is determined by it. In practice, it is a suitable legal form for business, especially for small start-up entrepreneurs. Among its other strengths, we advise a fairly simple way of setting up, a clear structure of organs, and a high degree of freedom of association due to the considerable flexibility of the law.

We considered it necessary in the context of the research to identify the whole-corporate interest in doing business in the form of a simple company on shares. For the overview we enclose the selected data. While in 2015-183,531 registered companies were registered in the business register, in 2016 it was 200,104. The most wanted form of business was a limited liability company, which was 176,956 in 2015. In 2016, number grew to 193,300. In 2015 , business register registered 5.340 join stock companies, and a year later it was 5.516. The number of public companies and limited companies has not been published for their low number by Statistical Offices of the Slovak Republic. So far, the results for 2017 are not known, that is why we were relatively intensive to count the number of simple companies on shares in the business register as of October 1 ,
2018. We found that only 98 simple companies on stocks were established in Slovakia at that date.

\section{DISCUSSION}

In the discussion, it is possible to argue with some opinions of other experts or the opinion of the legislator. As the most fundamental issue we see the legal definition of a simple company on shares which is identical to the definition of a joint stock company and is only taken over by the legislator from the Paragraph 154, Section 1 of the Commercial Code. As it is about the same definition of two companies, it is more than questionable in the opinion of the legislator that the two types of companies are different. Until 2017, the Commercial Code was recognized by four business companies, a public company, a limited partnership, a limited liability company and a joint stock company. Each of them has a separate definition that makes them unique subjects. It is possible to agree with the opinion of Suchoža et al. that if the legislature wanted to define it as a unique entity intended to support startups, it had to be defined differently. This deficiency is chaotic and the subject sounds rather than just a certain modification of a joint-stock company. This is also our opinion from the Statutes of Paragraph 220 h, Paragraph 3 of the Commercial Code, which enshrines the supportive application of the provisions on a joint stock company for a simple company. We see another issue in the question of delivery for voting outside the General Assembly. The legislator did not even deal with only the possible theoretical problems - not delivering the shipment from the shareholder containing his voice, which he had already pointed out, for example, J. Csach. The solutions are in our opinion two; the first is the Statutes of Paragraph 190b and $190 \mathrm{c}$ of the Commercial Code on Correspondent Vote. The second, with regard to availability of information technology, would be to introduce a vote by electronic mail. Unlike the document, it is possible without doubt to prove the actual content of the mail delivered by electronic mail.

For the next legislative deficit we consider the non-determination of the minimum number of members of the Board of Directors. The legislature apparently relied on a linguistic and logical interpretation of this term, which implies that it is a collective body. The registry courts have a different viewpoint when they write in a business register a simple company on shares with a single member of the board - its chairman.

\section{CONCLUSION}

From the survey results, we found that a simple company's law on shares is likely to require several changes in the future. The legislator could modify its definition in order to avoid discussing whether it is a new type of joint-stock company. For its greatest deficiency, in particular in relation with creditors, we consider the complete absence of any shareholder liability for the company's liabilities, which allows the shareholder to behave indifferently to its "owner". This is especially the economic risk to the company's potential 
business partners. We are of the opinion that at least the limited statutory liability of the shareholder for the company's liabilities would motivate him to behave responsibly when deciding on the direction of the company. The question is also the way of its internal functioning, especially if the shareholders "do not undermine" the content of the statutes. Originally, a simple company on shares was exempt from a tax license. From January $1^{\text {st }} 2018$, this duty expired for everyone, and this fact is likely to reduce interest in this legal form of business. The declared basic benefit of a simple company on shares is almost no equity ( 1 euro) and it is unconvincing. The Business Code identifies business companies that do not need to create equity, or the capital may also have a non-monetary form. In our own experience we know that it is almost impossible to do business without admission capital. In the context with the establishment and formation of a simple company on shares, it is also necessary to take into account the costs associated with the preparation of a founding document in the form of a notarial record of a legal act or a court fee for registration of the company in the commercial register of EUR 300. Given the number of simple companies on shares, we can state that the intention of the legislator to create a new type of business company as well, in terms of effective management of public finances, to be incorrect. We are convinced that the legislator could have been inspired by the Czech law on corporations, which in 2012 has modified a limited liability company. It is a transitory form of a business company that has the benefits of both private and capital companies. The advantage of this legal form of a company compared to a simple company on shares is manifested in particular by an unlimited number of shareholders, the ability of the partners to leave the company or changes in the social contract. In conclusion, based on the arguments, we reject the hypothesis on the suitability of a simple company for shares as a startup support.

\section{REFERENCES}

AUGUSTINIČ, I. 2006. European Joint Stock Company [in Slovak: Európska akciová spoločnost']. Justičná revue, 52(2): 325-345.

CSACH, K. 2009. Standard contracts [in Slovak: Štandardné zmluvy]. 1 ${ }^{\text {st }}$ Edition. Plzeň: Aleš Čenek.

DĚDIČ, J. and ČECH, P. 2006. European (Joint Stock) Company [in Czech: Evropská (akciová) společnost]. $1^{\text {st }}$ Edition. Praha: Bova Polygon.

DĚDIČ, J. and PAULY, J. 1994. Securities [in Czech: Cenné papíry]. 1 ${ }^{\text {st }}$ Edition. Praha: Prospektrum.

DVOǨÁK, T. 2016. Joint Stock Company [in Czech: Akciová společnost']. $1^{\text {st }}$ Edition. Praha: Wolters Kluwer.

ELIÁŠ, K. 2000. The joint stock company and systematical interpretation of general stock law with a view to its reform [in Czech: Akciová společnost systematický výklad obecného akciového práva se zřetelem k jeho reformè]. $1^{\text {st }}$ Edition. Praha: Linde.

JANAČ, V. 2017. The right to request the acquisition of a share (shoot-out right) [in Slovak: Právo požadovat' nadobudnutie akcii (shoot-out právo)]. Právny obzor, 100(2): 611-621.

SUPREME COURT OF THE SLOVAK REPUBLIC. 1997. Judgement no. 5 Obdo 8/1997. Rozhodnutie: Právna forma podnikania je súčastou obchodného mena a ak chýba treba ju doplnit'. V prípade súdneho sporu však uvedený nedostatok nemožno pokladat za neodstránitel'nú prekážku, ale za neúplné podanie, ktoré môže súd odstránit. Bratislava: Supreme Court of the Slovak Republic.

SUPREME COURT OF THE SLOVAK REPUBLIC. 2001. Judgement no. M Obdo 4/2001. Rozhodnutie: Za prípadnú škodu, ktorá vznikla v súvislosti s nesplnením záväzku akcionára splatit akcie, ktorý vyplýva zo zakladatel'skej zmluvy, preto nezodpovedá akciová spoločnost', ked'že ide o porušenie povinnosti akcionára, a nie spoločnosti. Bratislava: Supreme Court of the Slovak Republic.

SUPREME COURT OF THE SLOVAK REPUBLIC. 2002. Judgement no. 2 Obdo 165/2002. Rozhodnutie: Je potrebné odlíšit odmenu za výkon funkcie členov predstavenstva a dozornej rady od určenia ich podielu na zisku (tantiému), pretože toto právo patrí valnému zhromaždeniu a len v prípade dosiahnutého zisku. Bratislava: Supreme Court of the Slovak Republic.

SUPREME COURT OF THE SLOVAK REPUBLIC. 2003. Judgement no. Obdo V 44/2003. Rozhodnutie: Do pôsobnosti valného zhromaždenia spoločnosti patrí aj zmena stanov v tej časti, ktorá sa týka formy a podoby akcii spoločnosti. Bratislava: Supreme Court of the Slovak Republic.

SUPREME COURT OF THE SLOVAK REPUBLIC. 2009. Judgement no. 16 Obdo 6/2009. Rozhodnutie: Súd pred vydaním rozhodnutia o zrušení spoločnosti zo zákona povinne zistuje, či má spoločnost' obchodný majetok. Bratislava: Supreme Court of the Slovak Republic.

KREJCI, H. 1995. Fundamentals of Business Law [in German: Grundriss des Handelrechts]. $1^{\text {st }}$ Edition. Wien: Manz.

KUBÍČEK, P., MAMOJKA, M. and PATAKYOVÁ, M. 2006. Business Law [in Slovak: Obchodnéprávo]. ${ }^{\text {st }}$ Edition. Bratislava: Právnická fakulta UK.

KUBINEC, M. 2015. Several comments on the new legislation of a company in crisis [in Slovak: Niekolko poznámok k novej právnej úprave spoločnosti v kríze]. Notitiae Novae Facultatis Iuridicae Universitatis Matthiae Beli Neosolii. $1^{\text {st }}$ Edition. Banská Bystrica: Právnická fakulta UMB.

MAMOJKA, M., BOHRNOVÁ, M., UŠIAKOVÁ, L. et al. 2016. Business Code Great comment [in Slovak: Obchodný zákonník velký komentâr]. Volume no. 1. $1^{\text {st }}$ Edition. Žilina: Eurokódex. 
MIHÁLIKOVÁ, A. and HORNIAKOVÁ, L. 2002. Theory of financial and monetary relations [in Slovak: Teória finančných a menových vzt'ahov]. 1 $^{\text {st }}$ Edition. Bratislava: Právnická fakulta UK.

MINISTRY OF FINANCE OF SLOVAK REPUBLIC. 2015. Concept for Startup Support and the Development of the Startup Ecosystem of the Slovak Republic. Ministry of finance of Slovak Republic. [Online]. Available at https://www.mfsr.sk/Default.aspx?CatID=84\&NewsID=854 [Accessed: 2018, February 10].

OVEČKOVÁ, O., ČERNEJOVÁ, A., LACOVÁ, L. et al. 2012. Business Code comment 1 [in Slovak: Obchodný zákonník komentár 1]. $3^{\text {rd }}$ Edition. Bratislava: IURA EDITION

PATAKYOVÁ, M., BARKOCI, S., BARTOVÁ,Z. et al.2013. Business Code Comment [in Slovak: Obchodnýzákonník Komentár]. $4^{\text {nd }}$ Edition. Praha: C. H. BECK.

POKORNÁ, J., VEČERKOVÁ, E. and PEKÁREK, M. 2015. Business Corporations and Unfair Competition [in Czech: Obchodní korporace a nekalá soutěž ]. $1^{\text {st }}$ Edition. Praha: Wolters Kluwer.

SLOVAKIA. 2015. Reasonable report to Bill. No. 389/2015 Coll. amending Act no. 513/1991 Coll. Business Code. Available at: https://www.nrsr.sk/web/Default.aspx?sid=zakony/zakon\&MasterID=5663

SCHMIDT, K., 1999. Business Law [in German: Handelsrecht]. $1^{\text {st }}$ Edition. München: Carl Heymmans Verlag.

SUCHOŽA, J., ĎURICA, M., PATAKYOVÁ, M. et al.2016. Commercial Code and related statutes comment [in Slovak: Obchodný zákonník a súvisiace predpisy komentár]. $4^{\text {nd }}$ Edition. Bratislava: Eurounion.

ŠULEKOVÁ, Ž. 2014. Principle of One Action - One vote and reflection on new types of action [in Slovak: Zásada jedna akcia - jeden hlas a úvaha nad novými druhmi akcii]. Právny obzor 97(6) 584-602.

WOJČÁK, E. 2017. Planning [in Slovak: Plánovanie]. 1 ${ }^{\text {st }}$ Edition. Bratislava: Ofprint.

ŽITŇANSKÁ, L. 2000. Protection of minority shareholders in company law [in Slovak: Ochrana menšinových akcionárov v práve obchodných spoločností]. $1^{\text {st }}$ Edition. Bratislava: IURA EDITION.

Česká a Slovenská federatívna republika. 1991. Zákon č. 513 zo dňa 5. 11. 1991 Obchodný zákonník. In: Zbierka zákonov ČSFR. Částka: 98: 2474-2565. Available at: https://www.slov-lex.sk/static/pdf/1991/513/ ZZ_1991_513_20180101.pdf

ČESKÁ REPUBLIKA. 2012. Zákon č. 90 ze dne 25. ledna 2012 o obchodních společnostech a družstvech (zákon o obchodních korporacích). In: Sbírka zákonu České republiky. Částka: 34/2012. Avalaible at: https:// www.zakonyprolidi.cz/cs/2012-90

SLOVENSKÁ REPUBLIKA. 2015. Zákon č. 389 zo dňa 15. 11. 2015 Zákon, ktorým sa mení a doplňa zákon č. 513/1991 Zb. Obchodný zákonník v znení neskorších predpisov a ktorým sa menia a dopIňajú niektoré zákony. In: Zbierka zákonov Slovenskej republiky. Čiastka 107: 4342-4332. Available at: https://www.slov-lex. sk/static/pdf/2015/389/ZZ_2015_389_20170101.pdf

Contact information

Tomáš Peráček: tomas.peracek@fm.uniba.sk

Boris Mucha: boris.mucha@fm.uniba.sk

Patrícia Brestovanská: patricia.brestovanska@fm.uniba.sk

Jana Kajanová: jana.kajanová@fm.uniba.sk 